\title{
Breast Cancer Metastases to Bone: Role of the Microenvironment
}

\author{
Jenna E. Fong and Svetlana V. Komarova \\ Faculty of Dentistry, McGill University, Montreal
}

Canada

\section{Introduction}

Bone is the preferred site for breast cancer metastasis, which leads to altered mineral metabolism, disruption of bone architecture, and considerable pain burden. Prior to homing to the bone, the primary breast tumour releases soluble factors that lead to the creation of a pre-metastatic niche in the bone, which then serves to attract and maintain invading breast cancer cells. Breast cancer cells actively influence resident bone cells, altering both the action of and cross-talk between bone forming osteoblasts and bone-destroying osteoclasts. Breast cancer cells inhibit osteoblast differentiation and prevent them from creating and mineralizing new bone. Immature osteoblasts act as part of a hematopoietic stem cell niche and provide an attachment site for breast cancer cells. Breast cancer cells also produce factors, such as parathyroid hormone-related protein (PTHrP), which induce osteoblasts to stimulate the production of the pro-resorptive cytokine RANKL and to inhibit the production of RANKL inhibitor, OPG. RANKL, together with other osteoclastogenic factors released from breast cancer cells, promotes the fusion and differentiation of osteoclasts, resulting in bone destruction. As a result of bone resorption, growth factors stored in the bone matrix, such as TGF $\beta$, are released and can further stimulate the proliferation and survival of tumour cells. Thus, the complex interactions between breast cancer cells and the bone microenvironment underlie the homing of the breast cancer to bone and the subsequent progression of osteolytic lesions. Current therapeutics against bone metastases aim to prevent osteoclastic bone resorption by blocking osteoclast differentiation or stimulating their apoptosis. The osteoblast provides a valuable potential target, as a source of osteoclastic differentiation factors, and a platform for cancer cell attachment. Recent results from basic and clinical research provide new targets to prevent the interactions between breast cancer cells and the bone microenvironment at different stages of the metastatic cascade.

\section{Chapter outline}

- Physiological regulation of breast and bone

- Breast Growth and Development

- Interactions of normal breast tissue with bone

- Breast carcinoma

- Bone Microenvironment 
- Bone structure and composition

- Bone functions

- Osteoclasts, osteoblasts and osteocytes: origins, differentiation, function, physiology, pathology

- Bone marrow and hematopoietic stem cell niche

- $\quad$ Bone cell communications during normal bone remodelling

- Homing of breast cancer cells to bone

- Creation of pre-metastatic niche

- Migration of breast cancer cells to bone

- Attachment proteins between breast cancer cells and the bone

- Osteomimicry

- Establishing of a metastatic tumor in the bone microenvironment

- Interactions with osteoblasts

- Inhibition of osteoblasts by breast cancer cells

- Contribution of osteoblasts to the creation of an osteolytic environment

- $\quad$ Role of osteoblasts in supporting breast cancer cells

- Interactions with osteoclasts

- Stimulation of osteoclasts by breast cancer cells

- Role of osteoclasts in supporting breast cancer cells

- Therapeutic targets in the bone microenvironment

- Conclusions

- References

\section{Physiological regulation of breast and bone}

\subsection{Breast growth and development}

Interactions of normal breast tissue with bone

The interactions of normal breast tissue with bone arise during childbearing and breastfeeding. A normal human fetus needs approximately $30 \mathrm{~g}$ of calcium to mineralize its skeleton during gestation (1), that leads to significant changes in calcium homeostasis during pregnancy, including adjustments in levels of parathyroid hormone (PTH), calcitonin and 1,25 dihydroxyvitamin $D[1,25[\mathrm{OH}] \mathrm{D}]$ (2). These hormones exhibit their effects through three main target tissues - the intestines, kidneys and bone (3). Parathyroid hormone related peptide (PTHrP) is a hormone closely related to PTH, but which is produced by local tissues, such as breast, and is important for its differentiation (4). In addition to its role in local tissue development, PTHrP can substitute for PTH in the tissues expressing their common receptor, and thus participate in calcium homeostasis by elevating $1,25(\mathrm{OH}) \mathrm{D}$ and suppressing $\mathrm{PTH}$, regulating placental calcium transport, and affecting bone resorption in the maternal skeleton (3). The regulation of calcium homeostasis by the lactating mammary gland may be of critical importance, since nursing humans secrete 300-400 mg of calcium into milk each day (5). The hormonal balance changes again during lactation, with still-reduced PTH levels, but normalized calcitonin and $1,25(\mathrm{OH}) \mathrm{D}$, and increased PTHrP (2). During this time, increased prolactin concentrations allow for the release of breast milk, and also act to enhance bone turnover (6,7). Suckling stimulates prolactin secretion and inhibits GnRH production, both of which reduce estradiol levels, leading to bone resorption (8). Bone resorption has been shown to increase during lactation, and bone formation to decrease, resulting in a loss of $5-10 \%$ of trabecular mineral 
content per month (9). Lactation-induced fragility fractures have been reported as a result, but are not common (10). Of interest, other important molecular mediators for the developing of lactating mammary gland are receptor activator of nuclear factor $\kappa \mathrm{B}$ (RANK) and its ligand RANKL, which are better known for their key role in regulating the formation of osteoclasts. Expression of RANKL in the mammary epithelium is induced by hormones increased during pregnancy, such as prolactin, progesterone, and PTHrP, and mice lacking RANKL or RANK cannot form lobuloalveolar mammary gland structures, resulting in complete inability to develop a lactating mammary gland (11). Thus, normal breast tissue can interact with bone through a system of hormonal regulators that are important during lactation, and it expresses molecular machinery that employs the same mediators to perform locally distinct functions (Figure 1).

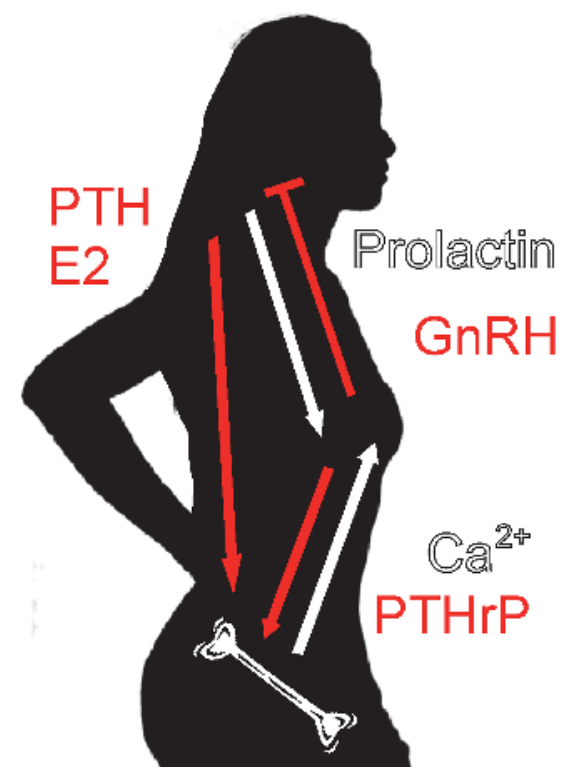

\section{RANK-RANKL lactating mammary gland differentiation}

\section{RANK-RANKL osteoclast differentiation}

Fig. 1. Physiological interactions between the functions of breast and bone. Lactation involves secretion of large amounts of calcium. Bone is a key participant in calcium homeostasis. PTH is reduced during lactation while PTHrP production by the breast tissue is increased. Suckling stimulates prolactin secretion and inhibits GnRH production, both of which reduce estradiol levels, leading to bone resorption. Prolactin and PTHrP induce breast expression of RANKL, necessary for normal lactating mammary gland function. In the bone tissue, osteoblast-produced RANKL is key regulator of osteoclastogenesis.

\section{Breast carcinoma}

Breast carcinomas may arise from the inner lining of the milk ducts or from the lobules, known, respectively, as ductal carcinomas or lobular carcinomas (12). Once a tumour exceeds 1-2 mm in diameter, it requires extensive vascularization in order to survive (13), but the speed of cancer growth often exceeds its capability to form normal vascular organization. Poor angiogenesis results in an under-vascularized microenvironment, which leads to hypoxia, acidic $\mathrm{pH}$ and nutrient depletion in the tumour (14). Some cancer cells may 
develop the ability to detach from the primary tumour and invade other areas to form secondary tumours, in a process called metastasis. Breast cancer cells favour regional lymph nodes as well as the liver, lungs, brain and bone as sites of metastasis (15). The metastatic process occurs in a complex series of interrelated steps. An epithelial-to-mesenchymaltransition (EMT) may occur whereby epithelial breast cancer cells take on a mesenchymal phenotype of reduced attachment to neighbouring cells and increased migratory capabilities (16). This may assist in their intravasation process, where the cell breaks through the epithelium into a blood vessel (17). From here, the cell migrates to a distant site, which is driven by chemotaxis and the communication between the cancer cell and a secondary site where it aims to establish (18-20). Instead of combating cancer cells, tumor-associated macrophages and T-cells may assist in the survival and dissemination of cancer cells by mitigating the immune response and promoting cancer progression $(21,22)$. When the cell has reached its destination, it will then undergo extravasation to exit the blood vessel and establish in a new tissue (23). Bone is a preferred site for breast cancer metastases, therefore specific interactions are likely to establish between breast cancer cells and bone cells.

\subsection{Bone microenvironment}

Bone is a dynamic tissue that provides support and protection for organs and maintains body mineral homeostasis. All 213 bones are constantly remodelled by the coordinated action of specialized bone cells-osteoclasts that destroy bone and osteoblasts that build bone. Bone remodelling contributes to the many functions that bones provide and occurs at different rates in different areas. Higher rates of bone turnover are observed in trabecular bone compared to cortical bone (24), and at bone sites adjacent to actively hematopoietic bone marrow in the axial skeleton, where bone metastases also commonly occur (25). High bone turnover has been found to correlate to poor prognosis in patients with bone metastases (26), and prostate cancer cells have been shown to preferentially metastasize to sites of active bone turnover (27), making bone homeostasis an essential part of understanding cancer progression.

\section{Structure}

The adult skeleton is composed of $80 \%$ solid and dense cortical bone, surrounding the remaining $20 \%$ trabecular bone, a network of plates and rods through the bone marrow (28). Bone is composed of an organic phase of extracellular matrix containing collagen- 1 triplehelical chains and non-collagenous proteins, and mineral phase of hydroxyapatite crystals $\left[\mathrm{Ca}_{10}\left(\mathrm{PO}_{4}\right)_{6}(\mathrm{OH})_{2}\right]$. Osteogenesis occurs by two distinct mechanisms - endochondral ossification, and intramembranous bone formation. Endochondral ossification occurs in most bones of mesodermal origin that form the axial skeleton, including long bones, skull, ribs and vertebrae, and involves the formation of initial mineralized cartilage template, which is first degraded by osteoclasts and then replaced with bone matrix by osteoblasts $(29,30)$. Intramembranous ossification occurs in the flat bones and the mandible, maxilla and clavicle, where an ossification centre is created when mesenchymal stem cells condense, and directly differentiate into bone-forming osteoblasts (31).

\section{Functions}

The mechanical functions of bone are probably their best recognized. Bones protect internal organs from damage and support the structure of the body. Bones provide anchorage for 
muscles, ligaments and tendons to allow movement in three-dimensional space. Hearing is also attributed to the mechanics of bones, with several of the body's smallest bones involved in the transmission of sound in the ear. Bone is the body's major reservoir of calcium, storing approximately $99 \%$ of it in the bone's mineral phase. Plasma calcium levels are strictly regulated in the range of $2.2-2.6 \mathrm{mmol} / \mathrm{L}$ total calcium. Such regulation is achieved by regulating calcium exchange with the environment through the kidney and intestine, and, in the absence or insufficiency of environmental sources, by regulating calcium exchange between plasma and bone through osteoblastic bone formation and osteoclastic bone destruction (32). The coordination of calcium fluxes is achived through complex hormonal regulation. Parathyroid hormone and 1,25 dihydroxy-vitamin D act to increase calcium by increasing calcium reabsorption from the kidneys and small intestine, respectively, and both act by enhancing the mobilization of calcium from bone through resorption (33). Calcitonin acts to reduce blood calcium by suppressing renal calcium reabsorption and inhibiting the mobilization from bone by preventing bone resorption (34). The combined work of these systems ensures that hypo- or hyper-calcemia is corrected, and ingested calcium is stored or eliminated as waste.

Bone tissue also interacts with other functionally diverse systems in the body. The endosteal surface of the medullary cavity of bones houses the haematopoietic stem cell niche, the specific location where blood stem cells best differentiate. Osteoblasts are well known to support the haematopoietic stem cell niche directly (35), and haematopoietic cells in turn regulate osteogenesis (36). Adipocyte-derived leptin regulates both appetite and bone mass accrual (37), and osteoblast-derived osteocalcin affects insulin secretion and sensitivity, as well as energy expenditure $(38,39)$. It has most recently been shown that the skeleton regulates male fertility through osteocalcin (40), extending the breadth of bone's influence into reproduction as well.

\section{Bone cells}

The three cell types critical to bone's structure and function are the bone-resorbing osteoclast, the bone forming osteoblast, and the mechanosensory osteocyte. These cells work in concert to build bones, maintain mechanically sound bone tissue by replacing it on average every 10 years, and repair bones in the incidence of trauma.

Osteoclasts: The destruction of bone, both physiological in the case of morphogenesis and replacing old or damaged bone, and pathological in the case of osteolytic diseases such as osteoporosis, breast cancer metastasis to bone and rheumatoid arthritis, occurs through the activity of the osteoclast. Osteoclasts are cells of hematopoietic origin. The key molecular mediators of osteoclast formation from monocytic precursors are macrophage colonystimulating factor (M-SCF) acting through its receptor c-fms, and RANKL which binds to its receptor RANK (41-43). Osteoprotegerin (OPG) is the high affinity decoy receptor for RANKL and is able to prevent osteoclast differentiation by inhibiting RANK-RANKL interactions (44). RANKL binding to RANK in the presence of M-CSF induces the recruitment of adaptor molecules including TRAF6 by RANK (45), resulting in the activation of transcription factor NFKB. One of the early targets of NFKB is another transcription factor essential for osteoclastogenesis, nuclear factor of activated T-cells c1 (NFATc1), which later undergoes auto-amplification with the assistance of an activator protein-1 complex containing c-Fos (46-48). NFATc1 nuclear localization is regulated by 
calcium signalling, which also activates calmodulin-dependent kinase, critical for further osteoclast differentiation (49). These events lead to the expression of osteoclast-specific genes including tartrate-resistant acid phosphatase (TRAP), cathepsin $\mathrm{K}$, and b3 integrin (50), which are important for the degradation of bone tissue. Osteoclasts resorb bone by creating a unique microenvironment localized between this cell and bone tissue. Osteoclasts first recognize and bind to the bone matrix with integrin receptors $\beta 1$ that bind collagen, fibronectin and laminin, and $\alpha v \beta 3$ that binds osteopontin and bone sialoprotein (51). This border forms a sealing zone over the area of bone to be resorbed, and the polarization of osteoclasts results in the formation of a ruffled border between the osteoclast and matrix (52). Targeted secretion of $\mathrm{H}^{+}$ions through the ruffled border $\mathrm{H}^{+}$ATPase, accompanied by movement of $\mathrm{Cl}^{-}$through chloride channels, acidifies the sealed space to a $\mathrm{pH}$ of approximately $4.5(53,54)$, resulting in dissolution of the mineral phase of bone, and proteolytic enzymes cathepsin K and matrix metalloproteinase-9 (MMP-9) are released and activated to digest the organic matrix (55).

Osteoblasts: Osteoblasts are differentiated from the mesenchymal stem cells (MSC) that can also give rise to progenitors of myoblasts, adipocytes and chondrocytes (56). Commitment of MSC to become osteoprogenitors results in the upregulation of receptors for hormones, cytokines and growth factors, including PTH, prostaglandin, interleukin-11, insulin-like growth factor- 1 and transforming growth factor- $\beta$ (57). Next, osteoprogenitor cells differentiate into preosteoblasts, cells that exhibit limited proliferation and start to express extracellular matrix proteins, such as collagen type I, bone sialoprotein and osteopontin. Preosteoblasts are also active in the production of pro-resorptive cytokine RANKL (58). Finally, mature osteoblasts do not proliferative, but actively produce and secrete collagen type I, bone sialoprotein and osteopontin as well as osteocalcin. In addition, mature osteoblasts switch to produce the RANKL inhibitor, OPG (58). Osteoblastogenesis commitment is driven by the downstream activities of Wingless-ints (Wnt) singling, the closely associated Hedgehog signalling pathway (Sonic Hedgehog, Indian Hedgehog) and bone morphogenetic proteins (BMPs), which determine where mesenchymal stem cells condense during embryonic patterning and cross-talk to induce osteoblast differentiation $(59,60)$. Another developmentally important pathway, Notch signalling, has been shown to negatively regulate osteoblast differentiation (61-63). Important signalling events during osteoblast differentiation include the activation of the runt-related transcription factor 2 (Runx2) transcription factor, which regulates the expression of the zinc finger-containing transcription factor Osterix (64). Osterix interacts with nuclear factor for activated T cells 2 (NFATc2), and in collaboration, controls the transcription of osteoblastic target genes osteocalcin, osteopontin, osteonectin and collagen-1 $(65,66)$. Osteoblasts anchor to newly formed bone matrix by cadherin- 11 and N-cadherin, and secrete type 1 collagen and noncollagenous matrix proteins (57). The osteoblasts then regulate the subsequent mineralization of extracellular matrix (67-69).

Osteocytes: While each cell type is essential for the maintenance of bone homeostasis, osteocytes are the most populous and account for over $95 \%$ of all cells in the skeleton, covering $94 \%$ of all bone surface (70). Osteocytes are differentiated from osteoblasts embedded in the bone matrix. During differentiation, the osteocyte cell body size decreases, and the number of long dendrite-like cell processes increases and they extend, connecting the cell with other osteocytes $(70,71)$. Osteocyte-specific genes are activated, including phosphate-regulating gene with homologies to endopeptidases on the $\mathrm{X}$ chromosome 
(PHEX), matrix extracellular phosphoglycoprotein (MEPE), dentin matrix protein 1 (DMP1), and fibroblast growth factor-23 (FGF23) (72,73). Osteocyte networks in the bone tissue are implicated in regulating the maintenance and mineralization of bone tissue $(70,74)$, through expression of sclerostin, a negative regulator of bone formation (75), as well as in sensing mechanical load in part through sheer stress generated by interstitial fluid moving through the lacuno-canalicular network (76). It has also been suggested that osteocytes participate in mineral homeostasis by resorbing the lacunar walls in which they are embedded (77-79).

Communication between bone cells during normal bone remodelling

Osteoblasts, osteoclasts and osteocytes must work in concert to maintain bone homeostasis (Figure 2). In normal bone physiology, the osteoclast will resorb worn or damaged bone, and then the osteoblast will form new bone in its place. The best studied example of the crosstalk between bone cells involves the RANK-RANKL-OPG triangle, where osteoblasts and osteocytes produce RANKL to promote osteoclast differentiation and survival, and OPG to prevent it, while osteoclasts express RANK, allowing them to respond to these regulatory cues. Many hormonal regulators of bone remodelling, such as PTH and estrogen, were demonstrated to act through changing the ratio of RANKL and OPG expression by osteoblasts (80). Interestingly, production of RANKL and OPG by osteoblasts is also regulated by their developmental stage, with immature osteoblasts producing more RANKL and mature osteoblasts produce more OPG, (58). Osteocytes also, at least in part, affect osteoclastogenesis through production of RANKL, which is induced in mechanicallystimulated osteocytes (81). Osteoclasts are in turn able to influence osteoblast activity. The concept of osteoclast-mediated osteoblastogenesis arose from the finding that $97 \%$ of new bone formation occurs in resorption pits (82). Several studies where osteoclasts have been genetically altered to have impaired function demonstrated diminished bone formation (83), and studies have begun to find mediators of this reversal coupling. Cardiotrophin- 1 is among the first identified, and is expressed by osteoclasts and increases osteoblast activity (84). Sphingosine-1-phosphate has been shown to act earlier and induce osteoblast precursor recruitment and subsequent mature cell survival (85). Ephrin-B2/EphB4 bidirectional signaling between osteoclasts and osteoblasts, has also been identified as a key mediator of contact-dependent communication. Forward signalling by ephrin-B2 on osteoclasts to EphB4 on osteoblasts activates bone formation, whereas reverse signalling from EphB4 on osteoblasts binding to ephrin-B2 on osteoclasts inhibits osteoclastogenesis (86). Since the ability for bone cells to communicate is essential for the maintenance of bone homeostasis, it can be anticipated that disruptions in these the complex networks would lead to profound consequences. Indeed, the RANKL/OPG ratio represents one of the key mediators of pathological bone destruction (87).

\section{Homing of breast cancer cells to bone}

\subsection{Creation of the pre-metastatic niche}

Recent evidence has led to the idea that the bone marrow supports a pre-metastatic niche - a site that receives signals from the primary tumour mass before dissemination, and changes the landscape of the target tissue to be conducive to tumour growth. It has been shown in mice treated with medium conditioned by tumour cells of different origin, the potential to home to different organs of subsequently injected cancer cells can be altered (88). In 
particular, in bone, bone marrow derived hematopoietic stem cells have been implicated in mediating the establishment of pre-metastatic niche $(19,88)$. Molecular mediators such as vascular endothelial growth factor (VEGF) receptor 1 (VEGFR1) and integrin $\alpha 4 \beta 1$ have been implicated in this process. VEGFR1 positive haematopoietic progenitor cells are recruited to sites of future metastasis (88). VEGF receptors are expressed by breast cancer cells as well as osteoclasts and osteoclast precursors, and VEGF expression correlates to increased tumour size and grade in humans (89). In addition, we have shown that breast cancer cells secrete factors that support the subsequent attachment of breast cancer cells acting at least in part through $\gamma$-secretase-mediated Notch signalling (20).

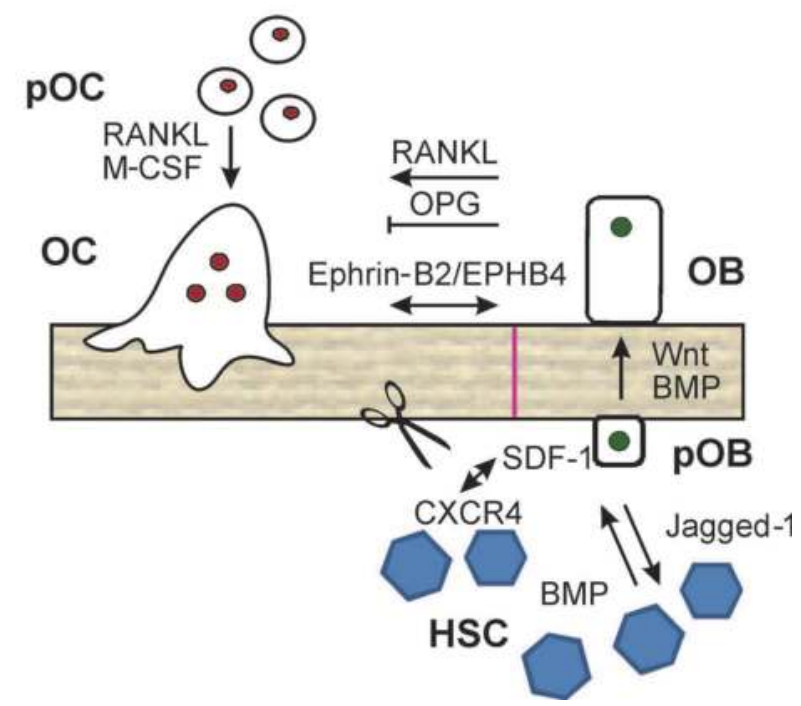

Fig. 2. Cell-cell interactions in the bone microenvironment. Osteoclast differentiation from monocytic precursors is induced by M-CSF, RANKL produced by osteoblastic cells. Osteoblasts are derived from mesenchymal stem cells through Wnt and BMP signalling pathways. Osteoblasts and osteoclasts communicate through osteoblast-derived RANKL/OPG and bidirectional Ephrin-B2/EphB4 signalling. Haematopoietic stem cells (HSC) support osteoblasts in the HSC niche through BMPs, while osteoblasts support HSCs through upregulated Notch signalling through Jagged-1. Osteoclasts cleave SDF-1 to mobilize HSCs from the endosteal niche.

\subsection{Migration of breast cancer cells to bone}

Breast cancer cells express receptors that direct their movement towards fertile sites where they may establish into secondary tumors. These proteins are generally expressed in normal cells, and are often involved in developmental pathways. Several chemokines have been suggested to be released from the bone microenvironment, implicating chemoattraction through G-protein-coupled chemokine receptors in driving the movement of tumour cells towards bone (90). Interactions between stromal-derived factor-1 (SDF-1) and CXCR4 are essential for the correct localization of lymphocytes and haematopoietic cells in physiological states. Breast cancer cells express higher levels of CXCR4 compared to normal 
breast tissue (15), and SDF-1 is strongly expressed in lung, liver, bone marrow and lymph nodes, the primary sites of secondary breast tumours, leading to the identification of the role of the SDF-1/CXCR4 in promoting breast cancer metastasis to bone (91). In addition to directional migration, chemokines have been shown to promote cancer cell survival, proliferation, and adhesion (92). In keeping, the inhibition of CXCR4 limited breast cancer metastases in mice (93), and the overexpression of CXCR4 indicates poor prognosis in both human and murine breast cancer $(92,94)$. Another chemokine implicated in metastases of breast cancer cells expressing high levels of CCL21, is CCR7 that is expressed highly in metastatic sites, such as lymph nodes (15). Since haematopoietic stem cells (HSCs) use these chemokine and receptor interactions to home to the HSC niche in the bone marrow, it has been suggested that cancer cells use this same mechanism to parasitize these microenvironments and harvest the resources of HSCs (95). Another pertinent means of cancer cell migration towards bone relies on the cancer cell expression of RANK (96), which mediates directional migration of breast, melanoma and prostate cancer cells towards RANKL, produced in bone by osteoblasts $(97,98)$.

Breast cancer cells may also stimulate the action of matrix metalloproteinases that support cancer cell migration and invasion. The murine orthologue of Glycogen Nonmetastatic Melanoma Protein B (GPNMB) is called osteoactivin and has been identified as a key modulator of osteolysis. Its forced expression leads to increased tumour grade and enhanced bone metastasis by upregulated MMP3 through ERK signaling $(99,100)$. Furthermore, GPNMB was identified as a poor prognostic marker in patients with breast cancer (101). Most recently, this group has identified ADAM10 as a sheddase that releases osteoactivin from the cell, which induces endothelial cell migration and subsequent angiogenesis (102). ADAMTS1 and MMP1 are also tumour-derived metalloproteinases able to degrade the matrix. The stimulated action of these enzymes by breast cancer cells enhances osteoclast differentiation by suppressing OPG expression, and their expression in human samples correlates to a greater incidence of bone metastases (103).

\subsection{Attachment proteins between breast cancer cells and the bone}

Cancer cells express or induce the expression of adhesion molecules that may facilitate their interactions with the bone microenvironment. The best studied family of proteins that bind cancer cells to bone cells are integrins, heterodimeric transmembrane glycoproteins whose $\alpha$ and $\beta$ subunits combine to form 24 known combinations with unique specificity for binding, signaling and regulatory mechanisms (104). Integrins have been demonstrated to be involved in several stages of cancer dissemination, with highly metastatic cancer cells displaying a different integrin profile than cells from the primary tumour (105). Several integrins have been shown to interact with extracellular matrix proteins during bone metastasis, with the most important being $\alpha v \beta 3$, a receptor for osteopontin, fibronectin and vitronectin (106). Adhesion molecules engaged between breast cancer cells and bone cells may overlap with those that bind haematopoietic stem cells (HSC) to osteoblasts. HSC preferentially home to areas with more fibronectin (88). Breast cancer cells can attach to fibronectin, in an integrin-dependent manner (107). The interaction of cancer cells with fibronectin increases the production of matrix metalloproteinase- 2 from fibroblasts to facilitate invasion (108). Another molecule involved the adhesion of HSC to the endosteal niche is annexin II (95). By serving as an anchor for SDF-1/CXCL12, it has been shown to regulate the homing of HSC as well as prostate cancer cells to the HSC niche $(109,110)$. 
Blocking annexin II or its receptor limited the localization of prostate cancer cells to osteoblasts and endothelial cells (111). In keeping, the inhibition of the SDF-1/CXCL12 and annexin II signaling was shown to inhibit breast cancer progression $(112,113)$. Bone matrix proteins, such as bone sialoprotein (BSP) or osteopontin (OPN) have been shown to exhibit a potential to regulate the attachment of breast cancer cells to bone (114). Early reports have argued that BSP inhibits breast cancer cell binding to bone cells (115). However, breast cancer cells have been shown to express both BSP and OPN, and to upregulate BSP expression in pre-osteoblasts through BMP signalling; and OPN was found localized between cancer cells and bone cells at sites of metastasis $(116,117)$. Moreover, the expression of BSP has been found to correlate with bone metastasis development (118), and OPN expression and serum concentrations have been shown to be poor prognosis markers in breast cancer patients $(119,120)$. As osteopontin is also a mediator of the hematopoietic stem cell niche, directing migration and acting as an adhesion molecule to HSC via $\beta 1$ integrin (121), it represents a potentially valuable therapeutic target against bone metastases.

\subsection{Osteomimicry}

Osteomimicry describes the phenomenon where osteotropic cancer cells express proteins and receptors found on bone cells and the bone matrix. It was speculated that such measures allow cancer cells to evade the immune system and/or establish in the bone microenvironment $(122,123)$. These proteins include but are not limited to osteocalcin, osteopontin, alkaline phopsphatase and Runx2 (124). Osteoblast transcription factor Runx2 is ectopically expressed by breast cancer cells and stimulates their proliferation, motility, and invasion through increased MMP9 expression from both cancer cells and osteoblasts $(125,126)$. Runx 2 has also been shown to regulate TGF $\beta$-influenced PTHrP levels, as well as upregulate Indian hedgehog (127). Breast cancer cells express Hedgehog ligands that activate osteopontin expression in osteoclasts, promoting osteoclast maturation and resorptive activity through upregulated Cathepsin K and MMP9 $(128,129)$. Of interest, expression of anti-resorptive OPG has been demonstrated to correlate with increased bonespecific homing and colonization potential in breast cancer cells (122), and to promote cancer cell survival $(130,131)$. Osteoclastic intergrin $\alpha v \beta 3(54)$, has been shown to be upregulated in metastatic versus primary tumour cells, and has been identified as a critical mediator of breast cancer metastasis to bone $(107,132)$. It is unclear whether cells from the primary tumour display osteomimetic features that allow their metastasis to bone, or whether secondary tumour cells established in the bone marrow and matrix receive environmental factors that give them their osteomimetic features. Regardless, the ability of cancer cells to produce many of these factors has been beneficial to thrive in the bone microenvironment.

\section{Establishing of a metastatic tumour in the bone microenvironment}

\subsection{Interactions of breast cancer cells with osteoblasts}

\section{Inhibition of osteoblasts by breast cancer cells}

Breast cancer metastasis to bone is associated with a reduction in bone formation markers in patients with bone metastases (133). In vitro, breast cancer cells have been shown to produce soluble factors able to inhibit osteoblast differentiation $(20,134)$, the effect that may be mediated at least in part by the dysregulation of Notch and Wnt developmental signalling 
pathways. Notch signalling is essential in embryogenesis but has distinct roles in bone homeostasis, regulating the proliferation of immature osteoblasts (135) and suppressing osteoblast differentiation $(62,63)$. Upregulated Notch signalling in breast cancer, through ligand Jagged-1, has been shown to correlate with increased bone metastases (136), and breast cancer cells have been shown to induce Jagged-1 expression and upregulate Notch signalling by osteoblasts (20). Wnt signaling is also a highly conserved developmental pathway, well studied in bone and essential for osteoblast and osteoclast differentiation, as well as for the production of pro-resorptive cytokine RANKL and anti-resorptive OPG (137). Wnt inhibitor DKK-1 has been shown to be upregulated in diseases associated with bone destruction, such as osteoarthritis (138), myeloma (139), and potentially in Paget's disease (140). Blocking DKK-1 in a breast cancer metastasis model has also been shown to reverse breast cancer-mediated suppression of osteoblast differentiation and reinstate OPG expression (141). Breast cancer cells have also been shown to induce osteoblast apoptosis, through increased Bax/Bcl-2 ratio and caspase expression in osteoblasts $(142,143)$. In addition to preventing the formation of new bone, breast cancer-induced inhibition of osteoblast differentiation likely indirectly contributes to the change in production of cytokines regulating osteoclast formation and function.

\section{Contribution of osteoblasts to the creation of an osteolytic environment}

The formation of an osteoclast-supportive microenvironment is critical for the successful establishment of an osteolytic lesion during breast cancer metastasis to bone. It has been previously shown that an increase in the ratio between a pro-resorptive RANKL and antiresorptive OPG is a key change induced by breast cancer cells (reviewed in $(144,145)$ ). Since osteoblasts are the primary source of both pro-resorptive and anti-resorptive cytokines, they represent a critical target for cancer-derived factors. Osteoblast production of RANKL is stimulated by tumour-derived PTHrP, Il-8, Il-6 and Monocyte Chemoattractant Protein (MCP-1) (reviewed in (146)). Moreover, under the influence of breast cancer cells, undifferentiated osteoblasts express higher levels of RANKL and lower OPG, resulting in an increase in osteoblast-mediated osteoclastogenesis (20), an effect that was reversed when osteoblastic cultures were treated with the inhibitors of $\gamma$-secretase - an enzyme implicated in Notch signalling $(20,136)$. One of the mediators of these changes was shown to be the tumour-overexpressed $\mathrm{CCN} 3$, that can inhibit osteoblast differentiation and shift the RANKL/OPG ratio to favour osteolysis (147). Another osteoblast-produced osteoclastogenic factor, MCSF, has also been implicated in breast cancer metastases to bone (148).

\section{Role of osteoblasts in supporting breast cancer cells}

An emerging area of interest is the role of osteoblasts in supporting the haematopoietic stem cell niche and how cancer cells parasitize this relationship. Haematopoiesis occurs on the endosteal surface of the bone marrow, where haematopoietic stem cells (HSCs) are maintained by the supporting cells, including osteoblasts. The main functions of the interaction between these cell types are $i$ ) the maintenance of HSC quiescence through osteoblast-derived osteopontin, and ii) modification to expand the progenitor population through Notch signaling $(35,121)$. Several osteoblast-expressed receptors, cytokines and growth factors have been found to regulate an haematopoietic stem cell niche $(149,150)$, including PTH/PTHrP receptors and BMPs acting to expand the osteoblast population, and Notch ligand Jagged-1 to expand the population of HSCs $(35,151)$. Cancer cells disseminated from the primary tumour may also lay dormant for long periods of time before being 
activated to form metastases (152), so it is plausible that cancer cells harvest resources from the HSCs niche to maintain their survival and to induce expansion at the right environmental cues.

\subsection{Interactions of breast cancer cells with osteoclasts}

Stimulation of osteoclasts by breast cancer cells

Breast cancer cells have been found to produce many factors capable of simulating osteoclastogenesis, both by inducing RANKL expression by osteoblasts and stromal cells, and by producing osteoclastogenic factors themselves. PTHrP was one of the first factors identified to be secreted by breast cancer cells and to promote osteolysis through the stimulation of RANKL by stromal cells (153). Although the expression of PTHrP in primary tumours has been associated with a lower incidence of bone metastasis $(154,155)$, it was shown that increased PTHrP expression by cancer cells present in the bone metastatic lesion positively correlates with increasing osteoclast activity and subsequent osteolysis (155), suggesting that the expression pattern of the cancer cells can change during metastasis, and implicating local factors, such as TGF $\beta$ derived from osteoclastic bone resorption in affecting metastasizing breast cancer cells. Osteoclastogenesis may also be stimulated by IL- 8 secreted from breast cancer cells and acting both directly on osteoclasts and through osteoblastic RANKL signalling $(156,157)$. Although the mechanisms of IL-8 action are not fully understood, the expression of IL-8 correlated with a higher incidence of bone metastasis in mice in vivo (158).

It has also been shown that during differentiation osteoclast precursors may acquire sensitivity to cancer-derived factors that are ineffective in inducing osteoclast formation from naive monocytes (159). Several signalling pathways in osteoclast precursors have been implicated in these effects, including calcium signalling, NFATc1 activation and MAPKs ERK1/2 and p38 $(159,160)$. Tumour-produced CCN3 was demonstrated to stimulate osteoclast formation from RANKL-primed osteoclast precursors (147). These effects can be relevant to the propensity of cancer cells to metastasize to bone sites undergoing active bone remodelling, and thus containing increased numbers of RANKL-primed osteoclast precursors. At such sites, breast cancer cells can promote further osteoclast formation, and can affect the survival of mature osteoclasts, increasing their resorptive capacity. In this regard, M-CSF secreted from breast cancer cells was shown to be responsible for the delayed apoptosis in osteoclasts $(146,161)$. Anti-apoptotic effects of breast cancer-derived factors included PLC $\gamma$-mediated suppression of pro-apoptotic protein BIM, and M-CSF-mediated inhibition of caspase cleavage (146).

Role of osteoclasts in supporting breast cancer cells

During osteoclastic resorption, the bone matrix components, including many growth factors stored in the bone, such as TGF $\beta$, BMPs, IGFs, fibroblast growth factors (FGFs), and plateletderived growth factors (PDGF) are released into extracellular space, where they are free to act on surrounding cells, including metastasizing cancer cells (162). Matrix released- TGF $\beta$ activated by osteoclastic resorption (163), is one of the most commonly studied matrixderived growth factors, which was shown to stimulate cancer cell growth, modify cell invasion, and affect immune regulation $(164,165)$. Considerable research has linked increased TGF- $\beta$ in the microenvironment to the progression of metastasis, with TGF $\beta$ 
altering both the growth and phenotype of breast cancer cells (166), and increasing their expression of CTGF, CXCL11 and PTHrP (167) via Smad and MAPK signalling in breast cancer cells $(153,168,169)$. PTHrP increases VEGF production, leading to stimulated osteoclastogenesis through the ERK1/2 and p38 signalling pathways (170). TGF $\beta$ also acts on other cells present in the bone microenvironment, such as osteoclasts themselves by sensitizing them to other breast cancer derived factors (159), through the ERK1/2, p38 and c-Jun- $\mathrm{NH}_{2}$ kinase signalling pathways $(160,171)$. In keeping with a key role of TGF $\beta$ in bone metastases, pharmacological inhibition of TGF $\beta$ signalling through the T $\beta$ RI kinase inhibitor SD-208 resulted in decreased bone metastasis and tumour burden, and improved bone quality (172). The self-accelerating cycle of osteoclast stimulation by breast cancer cells, resulting in release of matrix growth factors due to osteoclastic resorption, leading to further stimulation of breast cancer cells and further increase in osteoclastic resorption was coined the name of "vicious cycle" (173), underlying the strong rationale for the use of antiresorptive drugs for the treatment of cancer metastases to bone.

\section{Therapeutic targets in the bone microenvironment}

The bone microenvironment presents multiple targets for developing therapeutic treatments targeting the homing of breast cancer cells to bone, as well as progression of bone metastatic lesions (Figure 3). Molecular mediators of critical events underlying the stimulation of bone resorption and inhibition of bone formation, as well as tumour supportive environmental changes and cellular targets have been explored for their benefits in treatment of osteolytic bone metastases.

Since its discovery, the RANKL pathway has been considered to be of important therapeutic value given its role in osteoclastogenesis mediating osteolysis and subsequently discovered breast cancer cell migration, underlying pre-metastatic homing. Fully human monoclonal antibody against RANKL, Denosumab, was approved for major North American and European markets in 2010 for the prevention of osteoporosis and skeletal related events in patients with bone metastases from solid tumours. Compared to the most potent osteoclasttargeting drug in the market, bisphosphonate zoledronic acid, Denosumab treatment further delayed the occurrence of the first skeletal related event (SRE), and provided a further reduction in bone turnover markers in breast cancer patients (174). In non-metastatic breast cancer patients additionally receiving adjuvant aromatase inhibitors, bone mineral density gains were greater with Denosumab treatment (175). Bisphosphonate-resistant patients with bone metastases from breast or prostate cancer also benefitted from Denosumab treatment, with most having normalized serum markers of bone resorption after 13 weeks of treatment (176). Although Denosumab proves an effective treatment option, long-term use and toxicity data remains unknown.

DKK-1 was identified as a key mediator of myeloma-induced inhibition of bone formation, and was demonstrated to play important role in breast cancer induced inhibition of osteoblastogenesis. Neutralizing anti-DKK-1 antibodies have demonstrated significant benefits in preclinical studies in mouse models of myeloma-induced bone disease, resulting in increased osteoblast numbers, reduced osteoclast numbers and increased bone volume, and stimulating interest in further development of this approach (177). Bortezomib, a proteasome inhibitor that among other proteins affects DKK-1 and BIM (a pro-apoptotic protein that mediates osteoclast apoptosis) $(178,179)$, was shown to inhibit 
osteoclastogenesis (180) and has been successful in combating the osteolytic effects of multiple myeloma (181), making it an attractive candidate for the prevention and treatment of breast cancer-induced osteolysis.

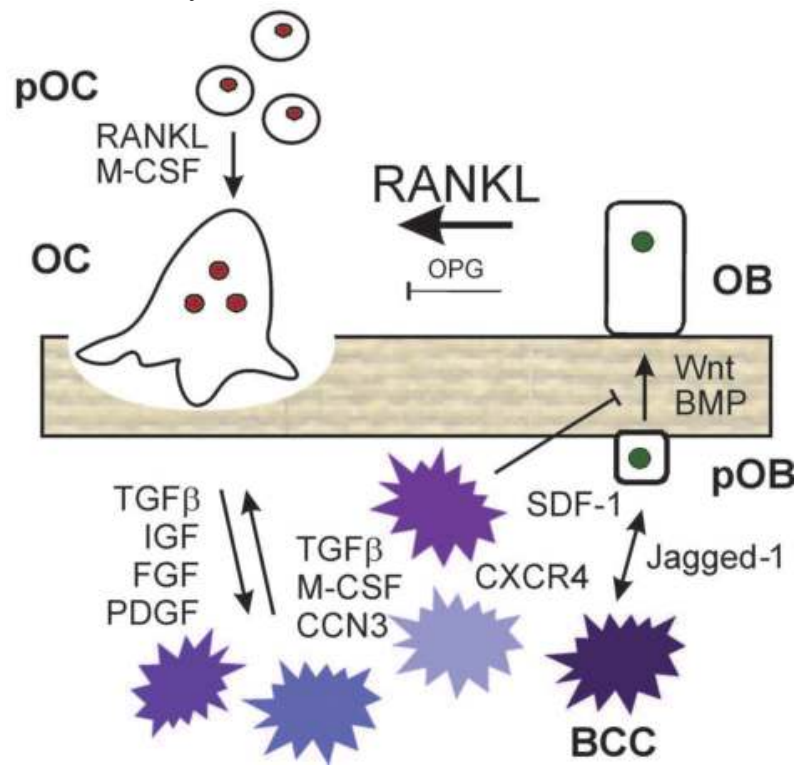

Fig. 3. Breast cancer cells alter normal bone homeostasis. Breast cancer cells maintain osteoblasts in an immature state and stimulate RANKL production by osteoblasts, while inhibiting OPG. Breast cancer cells stimulate osteoclastogenesis directly through TGF $\beta$, M$\mathrm{CSF}$ and $\mathrm{CCN} 3$ production. Increased bone resorption by activated osteoclasts releases matrix-derived growth factors TGF $\beta$, IGF, FGF, PDGF, which act back on breast cancer cells to stimulate their growth and survival.

VEGF represents an interesting target potentially affecting breast cancer cell homing, development of pre-metastatic niche and new vasculature formation. Many anti-VEGF therapies exist to prevent vascularization of tumours and inhibit their growth (182). There have been several hindrances in the progress of this therapy due to drug resistance and toxicity (183), and the increased incidence of osteonecrosis of the jaw in combined bisphosphonate-antiangiogenic agent therapy (184). Notwithstanding, the use of VEGF-A monoclonal antibody Bevacizumab in combination with chemotherapy has proven beneficial in reducing breast cancer growth (185) and osteolysis (186). Other targets based on the in vitro and in vivo studies, such as TGF $\beta$, GPNMB, and CXCR4 are being explored in preclinical and clinical studies, providing the basis for the next generation of treatments.

Osteoclasts are commonly targeted therapeutically for osteolytic disease, with one of the most widely used drugs being bisphosphonates. Analogs of mineralization-inhibiting pyrophosphate (187), bisphosphonates are a class of synthetic compounds composed of two phosphate groups covalently linked to carbon with a P-C-P backbone and side groups that vary their properties and pharmacokinetics. Bisphosphonates attach selectively to bone and induce osteoclast apoptosis when they are ingested during resorption. In osteoporosis studies, all bisphosphonates given daily have been shown to reduce osteoporotic vertebral 
fracture rates by $40-50 \%$ (188), and zoledronic acid and risedronate have been shown to significantly reduce non-vertebral fracture risk in pivotal trials (189). Bisphosphonates are widely used in prevention and treatment of breast cancer metastases to bone, resulting in delay and reduction in skeletal related events (190). In addition to their effects on osteoclasts, bisphosphonates have been shown to inhibit tumour growth, induce tumour cell apoptosis, and stimulate the immune response against tumour cells (191). However, some patients do not tolerate bisphosphonates well, and low but significant incidences of osteonecrosis of the jaw have been observed in patients that have undergone dental extraction procedures while treated with bisphosohonates (192). In addition, significant proportion of patients failed to normalize bone resorptive indices in response to bisphosphonate treatment (176), demonstrating the need for new therapeutic approaches.

\section{Conclusion}

Breast cancer is the most commonly diagnosed cancer in women, which may lead to bone metastasis resulting in altered mineral homeostasis, the disruption of bone microarchitecture, pain and pathological fractures. Recent studies have demonstrated that breast cancer cells start affecting the bone microenvironment prior to their dissemination from the primary tumour by secreting circulating soluble factors that prepare bone for the future arrival of metastasizing cancer cells, a process that likely involves mediators of the hematopoietic stem cell niche. Multiple mediators of directional migration of breast cancer cells have been identified, as well as mediators of breast cancer cells anti-osteoblastic and pro-osteoclastic actions. Breast cancer-stimulated RANKL, M-CSF, PTHrP, TGF $\beta$, GPNMB, Runx2 and CXCR4 remain among the most critical mediators of cancer-induced osteoclastic bone resorption. Yet, they are not the whole picture, and new players are being identified, providing more complex and comprehensive description of the events leading from the formation of primary tumour to the establishment of progressive osteolytic bone lesions. However, while considering the multitude of molecular mediators, it is important to remember the heterogeneity of breast cancer disease in patients, suggesting that treatments targeting different molecular mediators should develop in parallel with the testing capabilities able to implicate a particular mediator in disease progression in a specific patient. An alternative approach is to target the processes and cellular targets similarly altered through different molecular mediators. An example of such approach is the clinical success of bisphosphonates, which broadly target osteoclast formation and activity. Nevertheless, both approaches need to be developed to provide clinicians with the set of tools for broad preventive measures, as well as for targeted personalized medicine for nonresponsive or atypical cases.

\section{References}

[1] Mitchell DM, Juppner H 2010 Regulation of calcium homeostasis and bone metabolism in the fetus and neonate. Current opinion in endocrinology, diabetes, and obesity 17(1):25-30.

[2] Kovacs CS, Kronenberg HM 1997 Maternal-fetal calcium and bone metabolism during pregnancy, puerperium, and lactation. Endocrine reviews 18(6):832-72. 
[3] Kovacs CS 2008 Vitamin D in pregnancy and lactation: maternal, fetal, and neonatal outcomes from human and animal studies. The American journal of clinical nutrition 88(2):520S-528S.

[4] Hens JR, Wysolmerski JJ 2005 Key stages of mammary gland development: molecular mechanisms involved in the formation of the embryonic mammary gland. Breast cancer research: BCR 7(5):220-4.

[5] Thomas M, Weisman SM 2006 Calcium supplementation during pregnancy and lactation: effects on the mother and the fetus. American journal of obstetrics and gynecology 194(4):937-45.

[6] Seriwatanachai D, Thongchote K, Charoenphandhu N, Pandaranandaka J, Tudpor K, Teerapornpuntakit J, Suthiphongchai T, Krishnamra N 2008 Prolactin directly enhances bone turnover by raising osteoblast-expressed receptor activator of nuclear factor kappaB ligand/osteoprotegerin ratio. Bone 42(3):535-46.

[7] Coss D, Yang L, Kuo CB, Xu X, Luben RA, Walker AM 2000 Effects of prolactin on osteoblast alkaline phosphatase and bone formation in the developing rat. American journal of physiology. Endocrinology and metabolism 279(6):E1216-25.

[8] Wysolmerski JJ 2010 Interactions between breast, bone, and brain regulate mineral and skeletal metabolism during lactation. Annals of the New York Academy of Sciences 1192:161-9.

[9] Kovacs CS, Fuleihan Gel H 2006 Calcium and bone disorders during pregnancy and lactation. Endocrinology and metabolism clinics of North America 35(1):21-51, v.

[10] Michalakis K, Peitsidis P, Ilias I 2011 Pregnancy- and lactation-associated osteoporosis: a narrative mini-review. Endocrine regulations 45(1):43-7.

[11] Fata JE, Kong YY, Li J, Sasaki T, Irie-Sasaki J, Moorehead RA, Elliott R, Scully S, Voura EB, Lacey DL, Boyle WJ, Khokha R, Penninger JM 2000 The osteoclast differentiation factor osteoprotegerin-ligand is essential for mammary gland development. Cell 103(1):41-50.

[12] Sariego J 2010 Breast cancer in the young patient. The American surgeon 76(12):1397400.

[13] Folkman J 1986 How is blood vessel growth regulated in normal and neoplastic tissue? G.H.A. Clowes memorial Award lecture. Cancer research 46(2):467-73.

[14] Vaupel P 2004 The role of hypoxia-induced factors in tumor progression. The oncologist 9 Suppl 5:10-7.

[15] Muller A, Homey B, Soto H, Ge N, Catron D, Buchanan ME, McClanahan T, Murphy E, Yuan W, Wagner SN, Barrera JL, Mohar A, Verastegui E, Zlotnik A 2001 Involvement of chemokine receptors in breast cancer metastasis. Nature 410(6824):50-6.

[16] Vincent-Salomon A, Thiery JP 2003 Host microenvironment in breast cancer development: epithelial-mesenchymal transition in breast cancer development. Breast cancer research : BCR 5(2):101-6.

[17] Thiery JP 2002 Epithelial-mesenchymal transitions in tumour progression. Nature reviews. Cancer 2(6):442-54.

[18] Karnoub AE, Dash AB, Vo AP, Sullivan A, Brooks MW, Bell GW, Richardson AL, Polyak K, Tubo R, Weinberg RA 2007 Mesenchymal stem cells within tumour stroma promote breast cancer metastasis. Nature 449(7162):557-63.

[19] Psaila B, Kaplan RN, Port ER, Lyden D 2006 Priming the 'soil' for breast cancer metastasis: the pre-metastatic niche. Breast disease 26:65-74. 
[20] Fong JE, Le Nihouannen D, Komarova SV 2010 Tumor-supportive and osteoclastogenic changes induced by breast cancer-derived factors are reversed by inhibition of \{gamma\}-secretase. The Journal of biological chemistry 285(41):31427-34.

[21] Mukhtar RA, Nseyo O, Campbell MJ, Esserman LJ 2011 Tumor-associated macrophages in breast cancer as potential biomarkers for new treatments and diagnostics. Expert review of molecular diagnostics 11(1):91-100.

[22] Watanabe MA, Oda JM, Amarante MK, Cesar Voltarelli J 2010 Regulatory T cells and breast cancer: implications for immunopathogenesis. Cancer metastasis reviews 29(4):569-79.

[23] McSherry EA, Donatello S, Hopkins AM, McDonnell S 2007 Molecular basis of invasion in breast cancer. Cellular and molecular life sciences : CMLS 64(24):3201-18.

[24] Silverberg SJ, Gartenberg F, Jacobs TP, Shane E, Siris E, Staron RB, McMahon DJ, Bilezikian JP 1995 Increased bone mineral density after parathyroidectomy in primary hyperparathyroidism. The Journal of clinical endocrinology and metabolism 80(3):729-34.

[25] Coleman RE 2006 Clinical features of metastatic bone disease and risk of skeletal morbidity. Clinical cancer research : an official journal of the American Association for Cancer Research 12(20 Pt 2):6243s-6249s.

[26] Brown JE, Cook RJ, Major P, Lipton A, Saad F, Smith M, Lee KA, Zheng M, Hei YJ, Coleman RE 2005 Bone turnover markers as predictors of skeletal complications in prostate cancer, lung cancer, and other solid tumors. Journal of the National Cancer Institute 97(1):59-69.

[27] Schneider A, Kalikin LM, Mattos AC, Keller ET, Allen MJ, Pienta KJ, McCauley LK 2005 Bone turnover mediates preferential localization of prostate cancer in the skeleton. Endocrinology 146(4):1727-36.

[28] Eriksen EF AD, Melsen F 1994 Bone Histomorphometry. Raven Press, New York.

[29] Olsen BR, Reginato AM, Wang W 2000 Bone development. Annual review of cell and developmental biology 16:191-220.

[30] Chung UI, Kawaguchi H, Takato T, Nakamura K 2004 Distinct osteogenic mechanisms of bones of distinct origins. Journal of orthopaedic science : official journal of the Japanese Orthopaedic Association 9(4):410-4.

[31] Ferguson CM, Miclau T, Hu D, Alpern E, Helms JA 1998 Common molecular pathways in skeletal morphogenesis and repair. Annals of the New York Academy of Sciences 857:33-42.

[32] Favus MJ GD 2008 Regulation of Calcium and Magnesium. In: Rosen CJ (ed.) Primer on the Metabolic Bone Diseases and Disorders of Mineral Metabolism, vol. Seventh Edition. American Society for Bone and Mineral Reserach, Washington, DC, pp 104-108.

[33] Poole KE, Reeve J 2005 Parathyroid hormone - a bone anabolic and catabolic agent. Current opinion in pharmacology 5(6):612-7.

[34] Boden SD, Kaplan FS 1990 Calcium homeostasis. The Orthopedic clinics of North America 21(1):31-42.

[35] Calvi LM, Adams GB, Weibrecht KW, Weber JM, Olson DP, Knight MC, Martin RP, Schipani E, Divieti P, Bringhurst FR, Milner LA, Kronenberg HM, Scadden DT 2003 Osteoblastic cells regulate the haematopoietic stem cell niche. Nature 425(6960):841-6. 
[36] Shiozawa Y, Jung Y, Ziegler AM, Pedersen EA, Wang J, Wang Z, Song J, Lee CH, Sud S, Pienta KJ, Krebsbach PH, Taichman RS 2010 Erythropoietin couples hematopoiesis with bone formation. PloS one 5(5):e10853.

[37] Yadav VK, Oury F, Suda N, Liu ZW, Gao XB, Confavreux C, Klemenhagen KC, Tanaka KF, Gingrich JA, Guo XE, Tecott LH, Mann JJ, Hen R, Horvath TL, Karsenty G 2009 A serotonin-dependent mechanism explains the leptin regulation of bone mass, appetite, and energy expenditure. Cell 138(5):976-89.

[38] Ferron M, Wei J, Yoshizawa T, Del Fattore A, DePinho RA, Teti A, Ducy P, Karsenty G 2010 Insulin signaling in osteoblasts integrates bone remodeling and energy metabolism. Cell 142(2):296-308.

[39] Fulzele K, Riddle RC, DiGirolamo DJ, Cao X, Wan C, Chen D, Faugere MC, Aja S, Hussain MA, Bruning JC, Clemens TL 2010 Insulin receptor signaling in osteoblasts regulates postnatal bone acquisition and body composition. Cell 142(2):309-19.

[40] Oury F, Sumara G, Sumara O, Ferron M, Chang H, Smith CE, Hermo L, Suarez S, Roth BL, Ducy P, Karsenty G 2011 Endocrine regulation of male fertility by the skeleton. Cell 144(5):796-809.

[41] Quinn JM, Gillespie MT 2005 Modulation of osteoclast formation. Biochemical and biophysical research communications 328(3):739-45.

[42] Pixley FJ, Stanley ER 2004 CSF-1 regulation of the wandering macrophage: complexity in action. Trends in cell biology 14(11):628-38.

[43] Lacey DL, Timms E, Tan HL, Kelley MJ, Dunstan CR, Burgess T, Elliott R, Colombero A, Elliott G, Scully S, Hsu H, Sullivan J, Hawkins N, Davy E, Capparelli C, Eli A, Qian YX, Kaufman S, Sarosi I, Shalhoub V, Senaldi G, Guo J, Delaney J, Boyle WJ 1998 Osteoprotegerin ligand is a cytokine that regulates osteoclast differentiation and activation. Cell 93(2):165-76.

[44] Yasuda H, Shima N, Nakagawa N, Yamaguchi K, Kinosaki M, Mochizuki S, Tomoyasu A, Yano K, Goto M, Murakami A, Tsuda E, Morinaga T, Higashio K, Udagawa N, Takahashi N, Suda T 1998 Osteoclast differentiation factor is a ligand for osteoprotegerin/osteoclastogenesis-inhibitory factor and is identical to TRANCE/RANKL. Proceedings of the National Academy of Sciences of the United States of America 95(7):3597-602.

[45] Kiviranta R, Morko J, Alatalo SL, NicAmhlaoibh R, Risteli J, Laitala-Leinonen T, Vuorio E 2005 Impaired bone resorption in cathepsin K-deficient mice is partially compensated for by enhanced osteoclastogenesis and increased expression of other proteases via an increased RANKL/OPG ratio. Bone 36(1):159-72.

[46] Takayanagi H, Kim S, Koga T, Nishina H, Isshiki M, Yoshida H, Saiura A, Isobe M, Yokochi T, Inoue J, Wagner EF, Mak TW, Kodama T, Taniguchi T 2002 Induction and activation of the transcription factor NFATc1 (NFAT2) integrate RANKL signaling in terminal differentiation of osteoclasts. Developmental cell 3(6):889-901.

[47] Ishida N, Hayashi K, Hoshijima M, Ogawa T, Koga S, Miyatake Y, Kumegawa M, Kimura T, Takeya T 2002 Large scale gene expression analysis of osteoclastogenesis in vitro and elucidation of NFAT2 as a key regulator. The Journal of biological chemistry 277(43):41147-56.

[48] Asagiri M, Takayanagi H 2007 The molecular understanding of osteoclast differentiation. Bone 40(2):251-64.

[49] Sato K, Takayanagi H 2006 Osteoclasts, rheumatoid arthritis, and osteoimmunology. Current opinion in rheumatology 18(4):419-26. 
[50] Takayanagi H 2007 The role of NFAT in osteoclast formation. Annals of the New York Academy of Sciences 1116:227-37.

[51] Ross FP, Teitelbaum SL 2005 alphavbeta3 and macrophage colony-stimulating factor: partners in osteoclast biology. Immunological reviews 208:88-105.

[52] Nakamura I, Gailit J, Sasaki T 1996 Osteoclast integrin alphaVbeta3 is present in the clear zone and contributes to cellular polarization. Cell and tissue research 286(3):507-15.

[53] Teitelbaum SL, Abu-Amer Y, Ross FP 1995 Molecular mechanisms of bone resorption. Journal of cellular biochemistry 59(1):1-10.

[54] Teitelbaum SL, Ross FP 2003 Genetic regulation of osteoclast development and function. Nature reviews. Genetics 4(8):638-49.

[55] Stenbeck G 2002 Formation and function of the ruffled border in osteoclasts. Seminars in cell \& developmental biology 13(4):285-92.

[56] Aubin JE 2001 Regulation of osteoblast formation and function. Rev Endocr Metab Disord 2(1):81-94.

[57] Zaidi M 2007 Skeletal remodeling in health and disease. Nature medicine 13(7):791-801.

[58] Gori F, Hofbauer LC, Dunstan CR, Spelsberg TC, Khosla S, Riggs BL 2000 The expression of osteoprotegerin and RANK ligand and the support of osteoclast formation by stromal-osteoblast lineage cells is developmentally regulated. Endocrinology 141(12):4768-76.

[59] Yuasa T, Kataoka H, Kinto N, Iwamoto M, Enomoto-Iwamoto M, Iemura S, Ueno N, Shibata Y, Kurosawa H, Yamaguchi A 2002 Sonic hedgehog is involved in osteoblast differentiation by cooperating with BMP-2. Journal of cellular physiology 193(2):225-32.

[60] Nakashima A, Katagiri T, Tamura M 2005 Cross-talk between Wnt and bone morphogenetic protein 2 (BMP-2) signaling in differentiation pathway of C2C12 myoblasts. The Journal of biological chemistry 280(45):37660-8.

[61] de Jong DS, Steegenga WT, Hendriks JM, van Zoelen EJ, Olijve W, Dechering KJ 2004 Regulation of Notch signaling genes during BMP2-induced differentiation of osteoblast precursor cells. Biochemical and biophysical research communications 320(1):100-7.

[62] Hilton MJ, Tu X, Wu X, Bai S, Zhao H, Kobayashi T, Kronenberg HM, Teitelbaum SL, Ross FP, Kopan R, Long F 2008 Notch signaling maintains bone marrow mesenchymal progenitors by suppressing osteoblast differentiation. Nature medicine 14(3):306-14.

[63] Zanotti S, Smerdel-Ramoya A, Stadmeyer L, Durant D, Radtke F, Canalis E 2008 Notch inhibits osteoblast differentiation and causes osteopenia. Endocrinology 149(8):3890-9.

[64] Nishio Y, Dong Y, Paris M, O'Keefe RJ, Schwarz EM, Drissi H 2006 Runx2-mediated regulation of the zinc finger Osterix/Sp7 gene. Gene 372:62-70.

[65] Nakashima K, Zhou X, Kunkel G, Zhang Z, Deng JM, Behringer RR, de Crombrugghe B 2002 The novel zinc finger-containing transcription factor osterix is required for osteoblast differentiation and bone formation. Cell 108(1):17-29.

[66] Schroeder TM, Jensen ED, Westendorf JJ 2005 Runx2: a master organizer of gene transcription in developing and maturing osteoblasts. Birth defects research. Part C, Embryo today : reviews 75(3):213-25.

[67] Hessle L, Johnson KA, Anderson HC, Narisawa S, Sali A, Goding JW, Terkeltaub R, Millan JL 2002 Tissue-nonspecific alkaline phosphatase and plasma cell membrane 
glycoprotein-1 are central antagonistic regulators of bone mineralization. Proceedings of the National Academy of Sciences of the United States of America 99(14):9445-9.

[68] Xu L, Anderson AL, Lu Q, Wang J 2007 Role of fibrillar structure of collagenous carrier in bone sialoprotein-mediated matrix mineralization and osteoblast differentiation. Biomaterials 28(4):750-61.

[69] Murshed M, McKee MD 2010 Molecular determinants of extracellular matrix mineralization in bone and blood vessels. Current opinion in nephrology and hypertension 19(4):359-65.

[70] Franz-Odendaal TA, Hall BK, Witten PE 2006 Buried alive: how osteoblasts become osteocytes. Developmental dynamics : an official publication of the American Association of Anatomists 235(1):176-90.

[71] Bonewald LF 2011 The amazing osteocyte. Journal of bone and mineral research : the official journal of the American Society for Bone and Mineral Research 26(2):229-38.

[72] Bonewald LF 2007 Osteocytes as dynamic multifunctional cells. Annals of the New York Academy of Sciences 1116:281-90.

[73] Bonewald LF, Johnson ML 2008 Osteocytes, mechanosensing and Wnt signaling. Bone 42(4):606-15.

[74] Palumbo C, Palazzini S, Zaffe D, Marotti G 1990 Osteocyte differentiation in the tibia of newborn rabbit: an ultrastructural study of the formation of cytoplasmic processes. Acta anatomica 137(4):350-8.

[75] Dallas SL, Bonewald LF 2010 Dynamics of the transition from osteoblast to osteocyte. Annals of the New York Academy of Sciences 1192:437-43.

[76] Kamel MA, Picconi JL, Lara-Castillo N, Johnson ML 2010 Activation of beta-catenin signaling in MLO-Y4 osteocytic cells versus 2T3 osteoblastic cells by fluid flow shear stress and PGE2: Implications for the study of mechanosensation in bone. Bone 47(5):872-81.

[77] Krempien B, Manegold C, Ritz E, Bommer J 1976 The influence of immobilization on osteocyte morphology: osteocyte differential count and electron microscopical studies. Virchows Archiv. A, Pathological anatomy and histology 370(1):55-68.

[78] Tazawa K, Hoshi K, Kawamoto S, Tanaka M, Ejiri S, Ozawa H 2004 Osteocytic osteolysis observed in rats to which parathyroid hormone was continuously administered. Journal of bone and mineral metabolism 22(6):524-9.

[79] Teti A, Zallone A 2009 Do osteocytes contribute to bone mineral homeostasis? Osteocytic osteolysis revisited. Bone 44(1):11-6.

[80] Locklin RM, Khosla S, Turner RT, Riggs BL 2003 Mediators of the biphasic responses of bone to intermittent and continuously administered parathyroid hormone. Journal of cellular biochemistry 89(1):180-90.

[81] Verborgt O, Tatton NA, Majeska RJ, Schaffler MB 2002 Spatial distribution of Bax and $\mathrm{Bcl}-2$ in osteocytes after bone fatigue: complementary roles in bone remodeling regulation? Journal of bone and mineral research : the official journal of the American Society for Bone and Mineral Research 17(5):907-14.

[82] Takahashi H, Epker B, Frost HM 1964 Resorption Precedes Formative Activity. Surgical forum 15:437-8.

[83] Martin TJ, Sims NA 2005 Osteoclast-derived activity in the coupling of bone formation to resorption. Trends in molecular medicine 11(2):76-81.

[84] Walker EC, McGregor NE, Poulton IJ, Pompolo S, Allan EH, Quinn JM, Gillespie MT, Martin TJ, Sims NA 2008 Cardiotrophin-1 is an osteoclast-derived stimulus of bone 
formation required for normal bone remodeling. Journal of bone and mineral research : the official journal of the American Society for Bone and Mineral Research 23(12):2025-32.

[85] Pederson L, Ruan M, Westendorf JJ, Khosla S, Oursler MJ 2008 Regulation of bone formation by osteoclasts involves Wnt/BMP signaling and the chemokine sphingosine-1-phosphate. Proceedings of the National Academy of Sciences of the United States of America 105(52):20764-9.

[86] Zhao C, Irie N, Takada Y, Shimoda K, Miyamoto T, Nishiwaki T, Suda T, Matsuo K 2006 Bidirectional ephrinB2-EphB4 signaling controls bone homeostasis. Cell metabolism 4(2):111-21.

[87] Boyce BF, Xing L 2008 Functions of RANKL/RANK/OPG in bone modeling and remodeling. Archives of biochemistry and biophysics 473(2):139-46.

[88] Kaplan RN, Riba RD, Zacharoulis S, Bramley AH, Vincent L, Costa C, MacDonald DD, Jin DK, Shido K, Kerns SA, Zhu Z, Hicklin D, Wu Y, Port JL, Altorki N, Port ER, Ruggero D, Shmelkov SV, Jensen KK, Rafii S, Lyden D 2005 VEGFR1-positive haematopoietic bone marrow progenitors initiate the pre-metastatic niche. Nature 438(7069):820-7.

[89] Aldridge SE, Lennard TW, Williams JR, Birch MA 2005 Vascular endothelial growth factor acts as an osteolytic factor in breast cancer metastases to bone. British journal of cancer 92(8):1531-7.

[90] Wilson TJ, Singh RK 2008 Proteases as modulators of tumor-stromal interaction: primary tumors to bone metastases. Biochimica et biophysica acta 1785(2):85-95.

[91] Zlotnik A 2006 Involvement of chemokine receptors in organ-specific metastasis. Contributions to microbiology 13:191-9.

[92] Dewan MZ, Ahmed S, Iwasaki Y, Ohba K, Toi M, Yamamoto N 2006 Stromal cellderived factor- 1 and CXCR4 receptor interaction in tumor growth and metastasis of breast cancer. Biomedicine \& pharmacotherapy $=$ Biomedecine \& pharmacotherapie 60(6):273-6.

[93] Liang Z, Wu T, Lou H, Yu X, Taichman RS, Lau SK, Nie S, Umbreit J, Shim H 2004 Inhibition of breast cancer metastasis by selective synthetic polypeptide against CXCR4. Cancer research 64(12):4302-8.

[94] Rhodes LV, Short SP, Neel NF, Salvo VA, Zhu Y, Elliott S, Wei Y, Yu D, Sun M, Muir SE, Fonseca JP, Bratton MR, Segar C, Tilghman SL, Sobolik-Delmaire T, Horton LW, Zaja-Milatovic S, Collins-Burow BM, Wadsworth S, Beckman BS, Wood CE, Fuqua SA, Nephew KP, Dent P, Worthylake RA, Curiel TJ, Hung MC, Richmond A, Burow ME 2011 Cytokine receptor CXCR4 mediates estrogen-independent tumorigenesis, metastasis, and resistance to endocrine therapy in human breast cancer. Cancer research 71(2):603-13.

[95] Jung Y, Wang J, Song J, Shiozawa Y, Havens A, Wang Z, Sun YX, Emerson SG, Krebsbach PH, Taichman RS 2007 Annexin II expressed by osteoblasts and endothelial cells regulates stem cell adhesion, homing, and engraftment following transplantation. Blood 110(1):82-90.

[96] Mori K, Ando K, Heymann D, Redini F 2009 Receptor activator of nuclear factor-kappa B ligand (RANKL) stimulates bone-associated tumors through functional RANK expressed on bone-associated cancer cells? Histology and histopathology 24(2):23542. 
[97] Armstrong AP, Miller RE, Jones JC, Zhang J, Keller ET, Dougall WC 2008 RANKL acts directly on RANK-expressing prostate tumor cells and mediates migration and expression of tumor metastasis genes. The Prostate 68(1):92-104.

[98] Jones DH, Nakashima T, Sanchez OH, Kozieradzki I, Komarova SV, Sarosi I, Morony S, Rubin E, Sarao R, Hojilla CV, Komnenovic V, Kong YY, Schreiber M, Dixon SJ, Sims SM, Khokha R, Wada T, Penninger JM 2006 Regulation of cancer cell migration and bone metastasis by RANKL. Nature 440(7084):692-6.

[99] Rose AA, Pepin F, Russo C, Abou Khalil JE, Hallett M, Siegel PM 2007 Osteoactivin promotes breast cancer metastasis to bone. Molecular cancer research : MCR 5(10):1001-14.

[100] Furochi H, Tamura S, Mameoka M, Yamada C, Ogawa T, Hirasaka K, Okumura Y, Imagawa T, Oguri S, Ishidoh K, Kishi K, Higashiyama S, Nikawa T 2007 Osteoactivin fragments produced by ectodomain shedding induce MMP-3 expression via ERK pathway in mouse NIH-3T3 fibroblasts. FEBS letters 581(30):5743-50.

[101] Rose AA, Grosset AA, Dong Z, Russo C, Macdonald PA, Bertos NR, St-Pierre Y, Simantov R, Hallett M, Park M, Gaboury L, Siegel PM 2010 Glycoprotein nonmetastatic $B$ is an independent prognostic indicator of recurrence and a novel therapeutic target in breast cancer. Clinical cancer research : an official journal of the American Association for Cancer Research 16(7):2147-56.

[102] Rose AA, Annis MG, Dong Z, Pepin F, Hallett M, Park M, Siegel PM 2010 ADAM10 releases a soluble form of the GPNMB/Osteoactivin extracellular domain with angiogenic properties. PloS one 5(8):e12093.

[103] Lu X, Wang Q, Hu G, Van Poznak C, Fleisher M, Reiss M, Massague J, Kang Y 2009 ADAMTS1 and MMP1 proteolytically engage EGF-like ligands in an osteolytic signaling cascade for bone metastasis. Genes \& development 23(16):1882-94.

[104] Schwartz MA, Schaller MD, Ginsberg MH 1995 Integrins: emerging paradigms of signal transduction. Annual review of cell and developmental biology 11:549-99.

[105] Edlund M, Miyamoto T, Sikes RA, Ogle R, Laurie GW, Farach-Carson MC, Otey CA, Zhau HE, Chung LW 2001 Integrin expression and usage by prostate cancer cell lines on laminin substrata. Cell growth \& differentiation : the molecular biology journal of the American Association for Cancer Research 12(2):99-107.

[106] Schneider JG, Amend SR, Weilbaecher KN 2011 Integrins and bone metastasis: integrating tumor cell and stromal cell interactions. Bone 48(1):54-65.

[107] van der P, Vloedgraven H, Papapoulos S, Lowick C, Grzesik W, Kerr J, Robey PG 1997 Attachment characteristics and involvement of integrins in adhesion of breast cancer cell lines to extracellular bone matrix components. Laboratory investigation; a journal of technical methods and pathology 77(6):665-75.

[108] Saad S, Gottlieb DJ, Bradstock KF, Overall CM, Bendall LJ 2002 Cancer cell-associated fibronectin induces release of matrix metalloproteinase-2 from normal fibroblasts. Cancer research 62(1):283-9.

[109] Shiozawa Y, Pedersen EA, Havens AM, Jung Y, Mishra A, Joseph J, Kim JK, Patel LR, Ying C, Ziegler AM, Pienta MJ, Song J, Wang J, Loberg RD, Krebsbach PH, Pienta KJ, Taichman RS 2011 Human prostate cancer metastases target the hematopoietic stem cell niche to establish footholds in mouse bone marrow. The Journal of clinical investigation.

[110] Jung Y, Shiozawa Y, Wang J, Patel LR, Havens AM, Song J, Krebsbach PH, Roodman GD, Taichman RS 2011 Annexin-2 is a regulator of stromal cell-derived factor- 
1/CXCL12 function in the hematopoietic stem cell endosteal niche. Experimental hematology 39(2):151-166 e1.

[111] Shiozawa Y, Havens AM, Jung Y, Ziegler AM, Pedersen EA, Wang J, Lu G, Roodman GD, Loberg RD, Pienta KJ, Taichman RS 2008 Annexin II/annexin II receptor axis regulates adhesion, migration, homing, and growth of prostate cancer. Journal of cellular biochemistry 105(2):370-80.

[112] Singh S, Srivastava SK, Bhardwaj A, Owen LB, Singh AP 2010 CXCL12-CXCR4 signalling axis confers gemcitabine resistance to pancreatic cancer cells: a novel target for therapy. British journal of cancer 103(11):1671-9.

[113] Sharma MR, Koltowski L, Ownbey RT, Tuszynski GP, Sharma MC 2006 Angiogenesisassociated protein annexin II in breast cancer: selective expression in invasive breast cancer and contribution to tumor invasion and progression. Experimental and molecular pathology 81(2):146-56.

[114] Takayama T, Suzuki N, Narukawa M, Goldberg HA, Otsuka K, Ito K 2005 Enamel matrix derivative is a potent inhibitor of breast cancer cell attachment to bone. Life sciences 76(11):1211-21.

[115] van der Pluijm G, Vloedgraven HJ, Ivanov B, Robey FA, Grzesik WJ, Robey PG, Papapoulos SE, Lowik CW 1996 Bone sialoprotein peptides are potent inhibitors of breast cancer cell adhesion to bone. Cancer research 56(8):1948-55.

[116] Ibrahim T, Leong I, Sanchez-Sweatman O, Khokha R, Sodek J, Tenenbaum HC, Ganss B, Cheifetz S 2000 Expression of bone sialoprotein and osteopontin in breast cancer bone metastases. Clinical \& experimental metastasis 18(3):253-60.

[117] Bunyaratavej P, Hullinger TG, Somerman MJ 2000 Bone morphogenetic proteins secreted by breast cancer cells upregulate bone sialoprotein expression in preosteoblast cells. Experimental cell research 260(2):324-33.

[118] Bellahcene A, Kroll M, Liebens F, Castronovo V 1996 Bone sialoprotein expression in primary human breast cancer is associated with bone metastases development. Journal of bone and mineral research : the official journal of the American Society for Bone and Mineral Research 11(5):665-70.

[119] Bramwell VH, Doig GS, Tuck AB, Wilson SM, Tonkin KS, Tomiak A, Perera F, Vandenberg TA, Chambers AF 2006 Serial plasma osteopontin levels have prognostic value in metastatic breast cancer. Clinical cancer research : an official journal of the American Association for Cancer Research 12(11 Pt 1):3337-43.

[120] Patani N, Jouhra F, Jiang W, Mokbel K 2008 Osteopontin expression profiles predict pathological and clinical outcome in breast cancer. Anticancer research 28(6B):410510.

[121] Nilsson SK, Johnston HM, Whitty GA, Williams B, Webb RJ, Denhardt DT, Bertoncello I, Bendall LJ, Simmons PJ, Haylock DN 2005 Osteopontin, a key component of the hematopoietic stem cell niche and regulator of primitive hematopoietic progenitor cells. Blood 106(4):1232-9.

[122] Kapoor P, Suva LJ, Welch DR, Donahue HJ 2008 Osteoprotegrin and the bone homing and colonization potential of breast cancer cells. Journal of cellular biochemistry 103(1):30-41.

[123] Garcia T, Jackson A, Bachelier R, Clement-Lacroix P, Baron R, Clezardin P, Pujuguet P 2008 A convenient clinically relevant model of human breast cancer bone metastasis. Clinical \& experimental metastasis 25(1):33-42.

[124] Rucci N, Teti A 2010 Osteomimicry: how tumor cells try to deceive the bone. Frontiers in bioscience 2:907-15. 
[125] Pratap J, Javed A, Languino LR, van Wijnen AJ, Stein JL, Stein GS, Lian JB 2005 The Runx2 osteogenic transcription factor regulates matrix metalloproteinase 9 in bone metastatic cancer cells and controls cell invasion. Molecular and cellular biology 25(19):8581-91.

[126] Leong DT, Lim J, Goh X, Pratap J, Pereira BP, Kwok HS, Nathan SS, Dobson JR, Lian JB, Ito Y, Voorhoeve PM, Stein GS, Salto-Tellez M, Cool SM, van Wijnen AJ 2010 Cancer-related ectopic expression of the bone-related transcription factor RUNX2 in non-osseous metastatic tumor cells is linked to cell proliferation and motility. Breast cancer research : BCR 12(5):R89.

[127] Pratap J, Wixted JJ, Gaur T, Zaidi SK, Dobson J, Gokul KD, Hussain S, van Wijnen AJ, Stein JL, Stein GS, Lian JB 2008 Runx2 transcriptional activation of Indian Hedgehog and a downstream bone metastatic pathway in breast cancer cells. Cancer research 68(19):7795-802.

[128] Das S, Samant RS, Shevde LA 2011 Hedgehog signaling induced by breast cancer cells promotes osteoclastogenesis and osteolysis. The Journal of biological chemistry 286(11):9612-22.

[129] Mi Z, Guo H, Wai PY, Gao C, Wei J, Kuo PC 2004 Differential osteopontin expression in phenotypically distinct subclones of murine breast cancer cells mediates metastatic behavior. The Journal of biological chemistry 279(45):46659-67.

[130] Holen I, Cross SS, Neville-Webbe HL, Cross NA, Balasubramanian SP, Croucher PI, Evans CA, Lippitt JM, Coleman RE, Eaton CL 2005 Osteoprotegerin (OPG) expression by breast cancer cells in vitro and breast tumours in vivo--a role in tumour cell survival? Breast cancer research and treatment 92(3):207-15.

[131] Fisher JL, Thomas-Mudge RJ, Elliott J, Hards DK, Sims NA, Slavin J, Martin TJ, Gillespie MT 2006 Osteoprotegerin overexpression by breast cancer cells enhances orthotopic and osseous tumor growth and contrasts with that delivered therapeutically. Cancer research 66(7):3620-8.

[132] Takayama S, Ishii S, Ikeda T, Masamura S, Doi M, Kitajima M 2005 The relationship between bone metastasis from human breast cancer and integrin alpha(v)beta3 expression. Anticancer research 25(1A):79-83.

[133] Mountzios G, Dimopoulos MA, Bamias A, Papadopoulos G, Kastritis E, Syrigos K, Pavlakis G, Terpos E 2007 Abnormal bone remodeling process is due to an imbalance in the receptor activator of nuclear factor-kappaB ligand (RANKL)/osteoprotegerin (OPG) axis in patients with solid tumors metastatic to the skeleton. Acta oncologica 46(2):221-9.

[134] Mercer RR, Miyasaka C, Mastro AM 2004 Metastatic breast cancer cells suppress osteoblast adhesion and differentiation. Clinical \& experimental metastasis 21(5):427-35.

[135] Engin F, Yao Z, Yang T, Zhou G, Bertin T, Jiang MM, Chen Y, Wang L, Zheng H, Sutton RE, Boyce BF, Lee B 2008 Dimorphic effects of Notch signaling in bone homeostasis. Nature medicine 14(3):299-305.

[136] Sethi N, Dai X, Winter CG, Kang Y 2011 Tumor-derived JAGGED1 promotes osteolytic bone metastasis of breast cancer by engaging notch signaling in bone cells. Cancer cell 19(2):192-205.

[137] Goldring SR, Goldring MB 2007 Eating bone or adding it: the Wnt pathway decides. Nature medicine 13(2):133-4.

[138] Diarra D, Stolina M, Polzer K, Zwerina J, Ominsky MS, Dwyer D, Korb A, Smolen J, Hoffmann M, Scheinecker C, van der Heide D, Landewe R, Lacey D, Richards WG, 
Schett G 2007 Dickkopf-1 is a master regulator of joint remodeling. Nature medicine 13(2):156-63.

[139] Qiang YW, Walsh K, Yao L, Kedei N, Blumberg PM, Rubin JS, Shaughnessy J, Jr., Rudikoff S 2005 Wnts induce migration and invasion of myeloma plasma cells. Blood 106(5):1786-93.

[140] McCarthy HS, Marshall MJ 2010 Dickkopf-1 as a potential therapeutic target in Paget's disease of bone. Expert opinion on therapeutic targets 14(2):221-30.

[141] Bu G, Lu W, Liu CC, Selander K, Yoneda T, Hall C, Keller ET, Li Y 2008 Breast cancerderived Dickkopf1 inhibits osteoblast differentiation and osteoprotegerin expression: implication for breast cancer osteolytic bone metastases. International journal of cancer. Journal international du cancer 123(5):1034-42.

[142] Fromigue O, Kheddoumi N, Lomri A, Marie PJ, Body JJ 2001 Breast cancer cells release factors that induced apoptosis in human bone marrow stromal cells. Journal of bone and mineral research : the official journal of the American Society for Bone and Mineral Research 16(9):1600-10.

[143] Mastro AM, Gay CV, Welch DR, Donahue HJ, Jewell J, Mercer R, DiGirolamo D, Chislock EM, Guttridge K 2004 Breast cancer cells induce osteoblast apoptosis: a possible contributor to bone degradation. Journal of cellular biochemistry 91(2):26576.

[144] Roodman GD, Dougall WC 2008 RANK ligand as a therapeutic target for bone metastases and multiple myeloma. Cancer Treat Rev 34(1):92-101.

[145] Santini D, Galluzzo S, Vincenzi B, Zoccoli A, Ferraro E, Lippi C, Altomare V, Tonini G, Bertoldo F 2010 Longitudinal evaluation of vitamin D plasma levels during anthracycline- and docetaxel-based adjuvant chemotherapy in early-stage breast cancer patients. Annals of oncology : official journal of the European Society for Medical Oncology / ESMO 21(1):185-6.

[146] Hussein O, Tiedemann K, Komarova SV 2011 Breast cancer cells inhibit spontaneous and bisphosphonate-induced osteoclast apoptosis. Bone 48(2):202-11.

[147] Ouellet V, Tiedemann K, Mourskaia A, Fong JE, Tran-Thanh D, Amir E, Clemons M, Perbal B, Komarova SV, Siegel PM 2011 CCN3 impairs osteoblast and stimulates osteoclast differentiation to favor breast cancer metastasis to bone. American Journal of Pathology (in press).

[148] Blouin S, Basle MF, Chappard D 2008 Interactions between microenvironment and cancer cells in two animal models of bone metastasis. British journal of cancer 98(4):809-15.

[149] Taichman RS, Emerson SG 1994 Human osteoblasts support hematopoiesis through the production of granulocyte colony-stimulating factor. The Journal of experimental medicine 179(5):1677-82.

[150] Taichman RS 2005 Blood and bone: two tissues whose fates are intertwined to create the hematopoietic stem-cell niche. Blood 105(7):2631-9.

[151] Zhang J, Niu C, Ye L, Huang H, He X, Tong WG, Ross J, Haug J, Johnson T, Feng JQ, Harris S, Wiedemann LM, Mishina Y, Li L 2003 Identification of the haematopoietic stem cell niche and control of the niche size. Nature 425(6960):836-41.

[152] Nash KT, Phadke PA, Navenot JM, Hurst DR, Accavitti-Loper MA, Sztul E, Vaidya KS, Frost AR, Kappes JC, Peiper SC, Welch DR 2007 Requirement of KISS1 secretion for multiple organ metastasis suppression and maintenance of tumor dormancy. Journal of the National Cancer Institute 99(4):309-21. 
[153] Yin JJ, Selander K, Chirgwin JM, Dallas M, Grubbs BG, Wieser R, Massague J, Mundy GR, Guise TA 1999 TGF-beta signaling blockade inhibits PTHrP secretion by breast cancer cells and bone metastases development. The Journal of clinical investigation 103(2):197-206.

[154] Powell GJ, Southby J, Danks JA, Stillwell RG, Hayman JA, Henderson MA, Bennett RC, Martin TJ 1991 Localization of parathyroid hormone-related protein in breast cancer metastases: increased incidence in bone compared with other sites. Cancer research 51(11):3059-61.

[155] Henderson M, Danks J, Moseley J, Slavin J, Harris T, McKinlay M, Hopper J, Martin T 2001 Parathyroid hormone-related protein production by breast cancers, improved survival, and reduced bone metastases. Journal of the National Cancer Institute 93(3):234-7.

[156] Bendre MS, Montague DC, Peery T, Akel NS, Gaddy D, Suva LJ 2003 Interleukin-8 stimulation of osteoclastogenesis and bone resorption is a mechanism for the increased osteolysis of metastatic bone disease. Bone 33(1):28-37.

[157] Bendre MS, Margulies AG, Walser B, Akel NS, Bhattacharrya S, Skinner RA, Swain F, Ramani V, Mohammad KS, Wessner LL, Martinez A, Guise TA, Chirgwin JM, Gaddy D, Suva LJ 2005 Tumor-derived interleukin-8 stimulates osteolysis independent of the receptor activator of nuclear factor-kappaB ligand pathway. Cancer research 65(23):11001-9.

[158] Bendre MS, Gaddy-Kurten D, Mon-Foote T, Akel NS, Skinner RA, Nicholas RW, Suva LJ 2002 Expression of interleukin 8 and not parathyroid hormone-related protein by human breast cancer cells correlates with bone metastasis in vivo. Cancer research 62(19):5571-9.

[159] Guo Y, Tiedemann K, Khalil JA, Russo C, Siegel PM, Komarova SV 2008 Osteoclast precursors acquire sensitivity to breast cancer derived factors early in differentiation. Bone 43(2):386-93.

[160] Tiedemann K, Hussein O, Sadvakassova G, Guo Y, Siegel PM, Komarova SV 2009 Breast cancer-derived factors stimulate osteoclastogenesis through the $\mathrm{Ca} 2+$ /protein kinase $\mathrm{C}$ and transforming growth factor-beta/MAPK signaling pathways. The Journal of biological chemistry 284(48):33662-70.

[161] Gallet M, Mentaverri R, Sevenet N, Brazier M, Kamel S 2006 Ability of breast cancer cell lines to stimulate bone resorbing activity of mature osteoclasts correlates with an anti-apoptotic effect mediated by macrophage colony stimulating factor. Apoptosis: an international journal on programmed cell death 11(11):1909-21.

[162] Mohan S, Baylink DJ 1991 Bone growth factors. Clinical orthopaedics and related research (263):30-48.

[163] Wilson TJ, Nannuru KC, Singh RK 2009 Cathepsin G-mediated activation of promatrix metalloproteinase 9 at the tumor-bone interface promotes transforming growth factor-beta signaling and bone destruction. Molecular cancer research : MCR 7(8):1224-33.

[164] Massague J 2008 TGFbeta in Cancer. Cell 134(2):215-30.

[165] Mourskaia AA, Northey JJ, Siegel PM 2007 Targeting aberrant TGF-beta signaling in pre-clinical models of cancer. Anti-cancer agents in medicinal chemistry 7(5):504-14.

[166] Kingsley LA, Fournier PG, Chirgwin JM, Guise TA 2007 Molecular biology of bone metastasis. Molecular cancer therapeutics 6(10):2609-17.

[167] Nannuru KC, Singh RK 2010 Tumor-stromal interactions in bone metastasis. Current osteoporosis reports 8(2):105-13. 
[168] Lindemann RK, Ballschmieter P, Nordheim A, Dittmer J 2001 Transforming growth factor beta regulates parathyroid hormone-related protein expression in MDA-MB231 breast cancer cells through a novel Smad/Ets synergism. The Journal of biological chemistry 276(49):46661-70.

[169] Kakonen SM, Selander KS, Chirgwin JM, Yin JJ, Burns S, Rankin WA, Grubbs BG, Dallas M, Cui Y, Guise TA 2002 Transforming growth factor-beta stimulates parathyroid hormone-related protein and osteolytic metastases via Smad and mitogen-activated protein kinase signaling pathways. The Journal of biological chemistry 277(27):24571-8.

[170] Isowa S, Shimo T, Ibaragi S, Kurio N, Okui T, Matsubara K, Hassan NM, Kishimoto K, Sasaki A 2010 PTHrP regulates angiogenesis and bone resorption via VEGF expression. Anticancer research 30(7):2755-67.

[171] Derynck R, Zhang YE 2003 Smad-dependent and Smad-independent pathways in TGF-beta family signalling. Nature 425(6958):577-84.

[172] Dunn LK, Mohammad KS, Fournier PG, McKenna CR, Davis HW, Niewolna M, Peng XH, Chirgwin JM, Guise TA 2009 Hypoxia and TGF-beta drive breast cancer bone metastases through parallel signaling pathways in tumor cells and the bone microenvironment. PloS one 4(9):e6896.

[173] Mundy GR 2002 Metastasis to bone: causes, consequences and therapeutic opportunities. Nat Rev Cancer 2(8):584-93.

[174] Stopeck AT, Lipton A, Body JJ, Steger GG, Tonkin K, de Boer RH, Lichinitser M, Fujiwara Y, Yardley DA, Viniegra M, Fan M, Jiang Q, Dansey R, Jun S, Braun A 2010 Denosumab compared with zoledronic acid for the treatment of bone metastases in patients with advanced breast cancer: a randomized, double-blind study. Journal of clinical oncology : official journal of the American Society of Clinical Oncology 28(35):5132-9.

[175] Ellis GK, Bone HG, Chlebowski R, Paul D, Spadafora S, Fan M, Kim D 2009 Effect of denosumab on bone mineral density in women receiving adjuvant aromatase inhibitors for non-metastatic breast cancer: subgroup analyses of a phase 3 study. Breast cancer research and treatment 118(1):81-7.

[176] Fizazi K, Lipton A, Mariette X, Body JJ, Rahim Y, Gralow JR, Gao G, Wu L, Sohn W, Jun S 2009 Randomized phase II trial of denosumab in patients with bone metastases from prostate cancer, breast cancer, or other neoplasms after intravenous bisphosphonates. Journal of clinical oncology : official journal of the American Society of Clinical Oncology 27(10):1564-71.

[177] Gavriatopoulou M, Dimopoulos MA, Christoulas D, Migkou M, Iakovaki M, Gkotzamanidou M, Terpos E 2009 Dickkopf-1: a suitable target for the management of myeloma bone disease. Expert opinion on therapeutic targets 13(7):839-48.

[178] Terpos E, Heath DJ, Rahemtulla A, Zervas K, Chantry A, Anagnostopoulos A, Pouli A, Katodritou E, Verrou E, Vervessou EC, Dimopoulos MA, Croucher PI 2006 Bortezomib reduces serum dickkopf-1 and receptor activator of nuclear factorkappaB ligand concentrations and normalises indices of bone remodelling in patients with relapsed multiple myeloma. Br J Haematol 135(5):688-92.

[179] Li C, Li R, Grandis JR, Johnson DE 2008 Bortezomib induces apoptosis via Bim and Bik up-regulation and synergizes with cisplatin in the killing of head and neck squamous cell carcinoma cells. Mol Cancer Ther 7(6):1647-55.

[180] von Metzler I, Krebbel H, Hecht M, Manz RA, Fleissner C, Mieth M, Kaiser M, Jakob C, Sterz J, Kleeberg L, Heider U, Sezer O 2007 Bortezomib inhibits human 
osteoclastogenesis. Leukemia : official journal of the Leukemia Society of America, Leukemia Research Fund, U.K 21(9):2025-34.

[181] Heider U, Kaiser M, Muller C, Jakob C, Zavrski I, Schulz CO, Fleissner C, Hecht M, Sezer O 2006 Bortezomib increases osteoblast activity in myeloma patients irrespective of response to treatment. European journal of haematology 77(3):233-8.

[182] Rosen LS 2005 VEGF-targeted therapy: therapeutic potential and recent advances. The oncologist 10(6):382-91.

[183] Koutras AK, Fountzilas G, Makatsoris T, Peroukides S, Kalofonos HP 2010 Bevacizumab in the treatment of breast cancer. Cancer treatment reviews 36(1):7582.

[184] Christodoulou C, Pervena A, Klouvas G, Galani E, Falagas ME, Tsakalos G, Visvikis A, Nikolakopoulou A, Acholos V, Karapanagiotidis G, Batziou E, Skarlos DV 2009 Combination of bisphosphonates and antiangiogenic factors induces osteonecrosis of the jaw more frequently than bisphosphonates alone. Oncology 76(3):209-11.

[185] Ortholan C, Durivault J, Hannoun-Levi JM, Guyot M, Bourcier C, Ambrosetti D, Safe S, Pages G 2010 Bevacizumab/docetaxel association is more efficient than docetaxel alone in reducing breast and prostate cancer cell growth: a new paradigm for understanding the therapeutic effect of combined treatment. European journal of cancer 46(16):3022-36.

[186] Bauerle T, Hilbig H, Bartling S, Kiessling F, Kersten A, Schmitt-Graff A, Kauczor HU, Delorme S, Berger MR 2008 Bevacizumab inhibits breast cancer-induced osteolysis, surrounding soft tissue metastasis, and angiogenesis in rats as visualized by VCT and MRI. Neoplasia 10(5):511-20.

[187] Addison WN, Azari F, Sorensen ES, Kaartinen MT, McKee MD 2007 Pyrophosphate inhibits mineralization of osteoblast cultures by binding to mineral, up-regulating osteopontin, and inhibiting alkaline phosphatase activity. The Journal of biological chemistry 282(21):15872-83.

[188] Keller MI 2004 Treating osteoporosis in post-menopausal women: a case approach. Cleveland Clinic journal of medicine 71(10):829-37.

[189] Rizzoli R 2011 Bisphosphonates for post-menopausal osteoporosis: are they all the same? QJM : monthly journal of the Association of Physicians 104(4):281-300.

[190] Aft R 2011 Bisphosphonates in breast cancer: clinical activity and implications of preclinical data. Clinical advances in hematology \& oncology : H\&O 9(3):194-205.

[191] Sun M, Iqbal J, Singh S, Sun L, Zaidi M 2010 The crossover of bisphosphonates to cancer therapy. Annals of the New York Academy of Sciences 1211:107-12.

[192] Bamias A, Kastritis E, Bamia C, Moulopoulos LA, Melakopoulos I, Bozas G, Koutsoukou V, Gika D, Anagnostopoulos A, Papadimitriou C, Terpos E, Dimopoulos MA 2005 Osteonecrosis of the jaw in cancer after treatment with bisphosphonates: incidence and risk factors. Journal of clinical oncology : official journal of the American Society of Clinical Oncology 23(34):8580-7. 


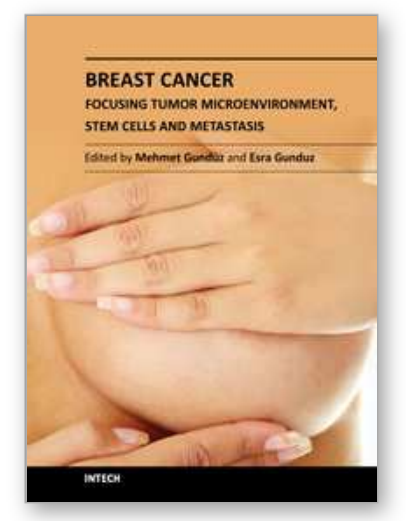

\author{
Breast Cancer - Focusing Tumor Microenvironment, Stem cells and \\ Metastasis \\ Edited by Prof. Mehmet Gunduz
}

ISBN 978-953-307-766-6

Hard cover, 584 pages

Publisher InTech

Published online 14, December, 2011

Published in print edition December, 2011

Cancer is the leading cause of death in most countries and its consequences result in huge economic, social and psychological burden. Breast cancer is the most frequently diagnosed cancer type and the leading cause of cancer death among females. In this book, we discussed characteristics of breast cancer cell, role of microenvironment, stem cells and metastasis for this deadly cancer. We hope that this book will contribute to the development of novel diagnostic as well as therapeutic approaches.

\title{
How to reference
}

In order to correctly reference this scholarly work, feel free to copy and paste the following:

Jenna E. Fong and Svetlana V. Komarova (2011). Breast Cancer Metastases to Bone: Role of the Microenvironment, Breast Cancer - Focusing Tumor Microenvironment, Stem cells and Metastasis, Prof. Mehmet Gunduz (Ed.), ISBN: 978-953-307-766-6, InTech, Available from:

http://www.intechopen.com/books/breast-cancer-focusing-tumor-microenvironment-stem-cells-andmetastasis/breast-cancer-metastases-to-bone-role-of-the-microenvironment

\section{INTECH}

open science | open minds

\section{InTech Europe}

University Campus STeP Ri

Slavka Krautzeka 83/A

51000 Rijeka, Croatia

Phone: +385 (51) 770447

Fax: +385 (51) 686166

www.intechopen.com

\section{InTech China}

Unit 405, Office Block, Hotel Equatorial Shanghai

No.65, Yan An Road (West), Shanghai, 200040, China

中国上海市延安西路 65 号上海国际贵都大饭店办公楼 405 单元

Phone: +86-21-62489820

Fax: +86-21-62489821 
(C) 2011 The Author(s). Licensee IntechOpen. This is an open access article distributed under the terms of the Creative Commons Attribution 3.0 License, which permits unrestricted use, distribution, and reproduction in any medium, provided the original work is properly cited. 